\title{
Health Impact of Gas Flares on Igwuruta / Umuechem Communities in Rivers State
}

\author{
${ }^{1}$ GOBO, A. E.; ${ }^{2}$ RICHARD G.; ${ }^{3}$ UBONG I. U. \\ ${ }^{1}$ \& 2 Institute of Geosciences and Space Technology (IGST), Rivers State University of Science and Technology, P.M.B 5080, Port \\ Harcourt, Nigeria.e-mail: safeearth@yahoo.com.au.08033108660 \\ ${ }^{3}$ Institute of Pollution Studies (IPS) Rivers State University of Science and Technology, P.M.B 5080, Port Harcourt, Nigeria.
}

\begin{abstract}
This paper examined the relationship between human exposure to toxicological factors in the environment arising from gas flares and the development of various human health related conditions. The impact of environmental factors was investigated at four stations set up concentrically around Agbada II flow station, for a period of nine months (May, 2007 - January, 2008) and sampling was performed manually across the four stations on an hourly basis. The analytical program was done in line with WMO recommendations. Parameters investigated include particulates and gases. Mean particulate concentrations in rainy season across all sites ranged from $0.4 \pm 0.4 \mu \mathrm{g} / \mathrm{m}^{3}$ in June to $25 \pm 5.4 \mu \mathrm{g} / \mathrm{m}^{3}$ in May. Concentration levels of particulates were excessive in the months of December and January, exceeding allowable regulatory limits for TSP, $\mathrm{PM}_{10}$ and $\mathrm{PM}_{7}$ across all stations. Mean concentration levels of gases in both wet and dry seasons were within allowable regulatory limits. Analysis of medical records showed a greater frequency of disease types such as Asthma, Cough, breathing difficulty, eye/skin irritation in (Igwuruta/Umuechem), the study area with a long history of gas flaring compared to Ayama with no flaring history. These subset of diseases accounted for $22.4 \%$ and $5.9 \%$ (a 4 to 1 ratio) of all cases reported at the respective health centers. The high level of particulates in the dry season constitutes a greater short-term exposure risk to residents and workers with the particular risk of respiratory irritation, itching/eye irritation and cough being endemic in the area surrounding the flare. @ JASEM
\end{abstract}

Oil and gas activities include drilling, refining and transportation of the finished product to consumers. During these activities, wastes either in solid, liquid or gaseous form are generated or discharged into the environment. Among the generated waste is flared gas. According to Egbuna, (1987), Natural gas is a mixture of hydrocarbons (containing mainly methane, ethane, propane and buthane, as well as, sometimes, their stable chemical derivatives such as ethylene, butylenes, etc.) occurring in a gaseous state at room temperature and pressure, and also containing other trace gaseous 'impurities' and noncombustibles (Egbuna, 1987). Stewart et al (1998) defined flaring as a combustion controlled process of volatile organic compounds (VOCs) in which the gases are piped to a remote, usually elevated location and burned in an open flame in the open air using a specially designed burner tip, auxiliary fuel and steam or air to promote mixing for gas destruction. In recent times, there has been reported cases of physiological effects recorded in areas with intense gas flaring and these effects include birth defects which occur during the reproductive cycle of women in their first trimester of pregnancy. Other effects are disturbance in the wake-sleep rhythm which is also associated with nervous problems and low ability to thrive among individuals found in similar area where gas flaring activities are taking place. This view is supported by the findings of Pope and Dockery (1996). In a related study, Calabrese and Kenyon (1991) reported cases of respiratory problems, skin/eye irritation, cancer and other ailments associated with exposure to gas flares in western Canada, (Calabrese and Kenyon, 1991). Godson, et al. (2005), discovered that compounds such as Sulphur oxides (SOx), carbon monoxide (CO), photochemical oxidants, Nitrogen oxides (NOx) and a number of other harmful compounds are contained in flared gases, these are believed to be associated with environmental pollution (Godson, et al, 1995).

Researchers have associated skin disorders and respiratory tract infections with exposure to high concentrations of atmospheric pollutants such as carbon monoxide (CO), Sulphur-dioxide $\left(\mathrm{SO}_{2}\right)$ and suspended particles, (Abbey et al, 1993; Wieslander et al, 1994; and Hall et al, 1995). According to James, (2001) Naphthalene is a hemolytic agent, destroying the membrane of the red blood cell with the liberation of hemoglobin, and an irritant of the eyes that may cause cataracts. The report pointed out that initial symptoms include eye irritation, headache, confusion, excitement, malaise, profuse sweating, nausea, vomiting, abdominal pain and irritation of the bladder. These few studies cited above have aroused interest in this field since communities in the Niger Delta share similar experiences.

This paper examines these problems in detail on a small scale by assessing the nature and effects of gas flares in terms of health and the environment in two communities around Agbada II flow station (Igwuruta and Umuechem). It is hoped that this paper would serve as a reference for Government and oil firms in delineating the health and environmental implications of gas flaring in the Niger Delta region when formulating policies or initiating actions that would be beneficial to those living within such vicinity.

\section{OBJECTIVES OF THE STUDY}

The objective of this paper is to examine the relationship between human exposure to toxicological factors in the environment arising from gas flares and the development of various human health related conditions, and identify various mitigation measures feasible where a correlation is established. The above objective is achieved through examination of changes in body 
functions occurring among individuals exposed to gas flares and examining health facilities available or in use to determine health problems associated with flared gases.

\section{STUDY AREA DESCRIPTION}

Agbada II flow station belonging to SPDC Nigeria limited is located between Eneka and Igwuruta communities in lkwerre Local Government Area of Rivers State. Geographically the facility is located on longitude $7^{\circ} 0^{\prime}-7^{0} 10^{\prime} \mathrm{E}$ and latitude $4^{0} 31^{\prime} 4^{0} 40^{\prime} \mathrm{N}$ in Rivers State of Nigeria (Gobo et al, 2006). The facility is bounded on the north by lgwuruta town, on the south by Eneka town, on the east by EnekaIgwuruta road and on the west by air Airport road. The facilityhas three different flare points consisting of two vertical and one horizontal flarepoints. Accessibility to the site is through a tarred road from the Eneka axis or Igwuruta Airport road. The facility is well fenced with an entrance gate in front and surrounded by farm lands.

\section{MATERIALS AND METHODS}

EPIDEMIOLOGICAL SURVEY: This paper looks into the impact of flared gases on human health using Igwuruta/Umuechem communities as a case study. The study covered the period May 2007 to January 2008. A mobile clinic was run to provide the researcher with current information on the epidemiological background of the inhabitants of the area under survey. Five hundred questionnaires requesting health information were distributed to inhabitants/workers in Igwuruta/Umuechem communities. In addition, four years medical records from the primary health care centre in Igwuruta were compared to that of Ayama in Abua/Odual local government area of Rivers State with no history of gas flaring.

AIR QUALITY: Three stations and one control area were defined. The four study sites were arranged concentrically about the flare points.

- $\quad$ Area I Upwind

- $\quad$ Area II Midpoint

- $\quad$ Area III Downwind

- $\quad$ Area IV Control

\section{FIELD SAMPLING}

Particulate matter and gases were collected at sites in Igwuruta. The samplers were approximately $200 \mathrm{~m}$ from the main roads to minimize the contributions of re-suspended soil dust from nearby streets. Sampling was performed during a 9 month period (May 2007- January 2008). Sample readings were taken at 3 different sites at approximately 1 hourly interval.

PARTICULATES: $\mathrm{PM}_{10}, \mathrm{PM}_{7}, \mathrm{PM}_{2.5}, \mathrm{PM}_{1}$ and TSP were collected using an Aerocet 531- 9800 Rev for the measurement of respirable particulate matter and TSP. The machine provides a fast indication of particulate mass concentration per cubic feet sampled air for the most commonly tested particle size fractions.

\section{GASES}

CARBON MONOXIDE (CO): A MultiRae PLUS Carbon Monoxide Gas monitor model PGM 7840 was used for the detection of Carbon monoxide. The range of detection is between $0-1000 \mathrm{ppm}$ with alarm set at 50 and $150 \mathrm{ppm}$. Measurements were done by holding the sensor to a height of about two meters in the direction of the prevailing wind and readings recorded at stability.

Sulphur oxides (SOx): A MultiRae PLUS Sulphur Oxides Gas monitor model PGM 7840 with an electrochemical sensor was used for the detection of SOx The range of detection is between $0-20 \mathrm{ppm}$ with a resolution of $0.1 \mathrm{ppm}$. The alarm set points (low/high) were at 2 and $10 \mathrm{ppm}$. Measurements were done by holding the sensor to a height of about two meters in the direction of the prevailing wind and readings recorded at stability.

NITROGEN DIOXIDES (NO2): A MultiRae PLUS Nitrogen Oxides Gas Monitor model PGM7840 with an electrochemical sensor was used for the detection of NOx. The range of detection is between 0 - $20 \mathrm{ppm}$ with a resolution of $0.1 \mathrm{ppm}$. The alarm set points (low/ high) were 1 and $10 \mathrm{ppm}$. Measurements were done by holding the sensor to a height of about two meters in the direction of the prevailing wind and readings recorded at stability.

HYDROGEN SULPHIDE $\left(\mathrm{H}_{2} \mathrm{~S}\right)$ : MultiRae PLUS Hydrogen Sulphide Gas Monitor model PGM 7840 was used for the detection or $\mathrm{H} 2 \mathrm{~S}$. The range of detection is between $0-20 \mathrm{ppm}$ with alarm set at 10 and $30 \mathrm{ppm}$. Measurements were done by holding the sensor to a height of about two meters in the direction of the prevailing wind and readings recorded at stability.

VOLATILE ORGANIC COMPOUNDS (VOCS): A MultiRae PLUS (PGM-50). A programmable Multi Gas monitor with an electrochemical sensor was used for the detection of volatile organic compounds. The equipment detects gas via a plug in catalytic head and has a detection range of 10 10004 ig VOCS Measurements were done by holding the sensor to a height of about two meters the direction of the prevailing wind and readings recorded at stability. The limit of detection is $0.01 \%$ volatile organic compounds.

\section{METHODS FOR ANALYSIS OF AIR QUALITY DATA}

Simple descriptive analysis involving mean, standard deviation and variance were used. A correlation analysis using ANOVA was carried out in order to ascertain the level of association between various chemical parameters. The student 
$\mathrm{t}$ - test was used to ascertain the statistical significance of the difference between means. The level of significance was taken as $p<0.01$. Graphs as well as tables were used to present data in a manner that could be easily understood.

\section{RESULTS AND DISCUSSION \\ t-TEST ANALYSIS: \\ PARTICULATES}

Table 1: $t$-test analysis of TSP at $99 \%$

\begin{tabular}{lll}
\hline t-Test: Two-Sample Assuming Equal Variances for TSPat 99\% \\
Of dry \& wet months at Downwind station \\
\multicolumn{1}{c}{ Dry season } & Wet season \\
Mean & 517.35 & 27 \\
Variance & 3144.25 & 24.5 \\
Observations & 2 & 2 \\
Pooled Variance & 1584.37 & \\
Hypothesized Mean Difference & 490.35 \\
Df & 2 & \\
$\mathrm{t}_{\text {Stat }}$ & 12.32 \\
$\mathrm{P}(\mathrm{T}<=\mathrm{t})$ one-tail & 0.00 \\
$\mathrm{t}_{\text {Critical }}$ one-tail & 6.96 \\
$\mathrm{P}(\mathrm{T}<=\mathrm{t})$ two-tail & 0.01 \\
$\mathrm{t}_{\text {Critical }}$ two-tail & 9.92 \\
\hline
\end{tabular}

Table 1 above is a summary of the results of t-Test analyses on TSP in dry/wet seasons at downwind station. The data indicates that variance arising from differences in stations was strongly significant $\left[\mathrm{t}_{\text {stat }}(12.32)>\mathrm{t}_{\text {crit }}(6.96) 0.01\right]$. Similarly t-Test results of $\mathrm{PM}_{10}$ and $\mathrm{PM}_{7}$ indicates significant variance $\left[\mathrm{t}_{\text {stat }}(7.17)>\mathrm{t}_{\text {crit }}(6.96) 0.01\right]$ and $\mathrm{PM}_{7}\left[\mathrm{t}_{\text {stat }}(66.65)>\right.$ tcrit $\left.(6.96) 0.01\right]$.

\section{GASES}

VOLATILE ORGANIC COMPOUNDS (VOCS): Table 2 below is a summary of the results of t-Test analyses on VOCs in dry/wet seasons across the stations. The data indicates that variance arising from differences in stations was not significant $\left[t_{\text {stat }}\right.$ $\left.(0.21)<t_{\text {crit }}(2.62) 0.01\right]$. Similarly $t-$ Test result for $\mathrm{CO}, \mathrm{NO}_{2}$, and $\mathrm{H}_{2} \mathrm{~S}$ were insignificant.

Table 2: t-test analysis of VOC at $99 \%$

\begin{tabular}{lll}
\hline t-Test: Two-Sample Assuming Equal Variances for VOC at $99 \%$ \\
of dry \& wet seasons at downwind & \\
& $\begin{array}{l}\text { Dry mths } \\
\text { Mean }\end{array}$ & Wet $m$ ths \\
Variance & 48.64 & 5.94 \\
Observations & 8.00 & 39.36 \\
Pooled Variance & 43.85 & 8.00 \\
Hypothesized Mean Difference & 0.00 & \\
Df & 14.00 & \\
$\mathrm{t}_{\text {Stat }}$ & 0.21 & \\
$\mathrm{P}(\mathrm{T}<=\mathrm{t})$ one-tail & 0.42 & \\
$\mathrm{t}_{\text {Critical }}$ one-tail & 2.62 \\
$\mathrm{P}(\mathrm{T}<=\mathrm{t})$ two-tail & 0.84 & \\
$\mathrm{t}_{\text {Critical }}$ two-tail & 2.98 \\
\hline
\end{tabular}

PARTICULATES AND GASES CORRELATION

Table 3: Correlation Analysis of all Parameters Investigated using ANOVA

\begin{tabular}{lllllllll}
\hline & $\mathbf{S O}_{\mathbf{2}}$ & $\mathbf{N O}_{\mathbf{2}}$ & $\mathbf{C O}$ & $\mathbf{T S P}$ & $\mathbf{P M}_{\mathbf{1 0}}$ & $\mathbf{P M}_{\mathbf{7}}$ & $\mathbf{P M}_{\mathbf{2 . 5}}$ & $\mathbf{P M}_{\mathbf{1}}$ \\
\hline $\mathrm{SO}_{2}$ & 1.00 & & & & & & & \\
$\mathrm{NO}_{2}$ & 0.79 & 1.00 & & & & & & \\
$\mathrm{CO}$ & 0.73 & 0.35 & 1.00 & & & & & \\
$\mathrm{TSP}$ & 0.98 & 0.66 & 0.79 & 1.00 & & & & \\
$\mathrm{PM}_{10}$ & 0.99 & 0.74 & 0.76 & 0.99 & 1.00 & & & \\
$\mathrm{PM}_{7}$ & 0.99 & 0.70 & 0.78 & 0.99 & 0.99 & 1 & & \\
$\mathrm{PM}_{2.5}$ & 0.98 & 0.89 & 0.68 & 0.92 & 0.96 & 0.95 & 1 & \\
\hline $\mathrm{PM}_{1}$ & 0.96 & 0.67 & 0.88 & 0.98 & 0.98 & 0.98 & 0.93 & 1 \\
\hline
\end{tabular}

* Corresponding author: ${ }^{1}$ Gobo, A. E. 
The Table above shows the correlation coefficients of various gases and particulates. The values generally imply a linear relationship between the parameters as the values are approximately equal to 1. The particulates TSP, $\mathrm{PM}_{10}, \mathrm{PM}_{7}, \mathrm{PM}_{2.5}, \mathrm{PM}_{1}$ all show strong and significant relationship $(\mathrm{r} \approx 1)$. Gases also show strongly significant correlation ( $\mathrm{r}$ $\approx 7$ ). The exception being that of Nitrogen dioxide $\left(\mathrm{NO}_{2}\right)$ and Carbon monoxide $(\mathrm{CO})$ which show little or no correlation $(\mathrm{r}=0.345783)$.

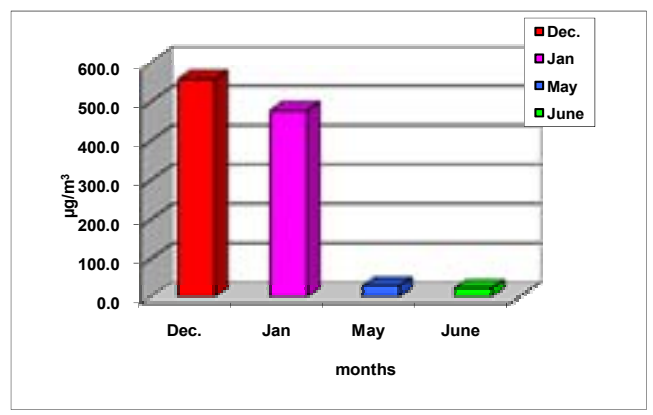

Fig. 1: Temporal distribution of TSP at Downwind station (Dec. 07 - Jan. 08)

The concentrations of $\mathrm{PM}_{7}$ were $160.3 \mu \mathrm{g} / \mathrm{m} 3$ and $168.7 \mu \mathrm{g} / \mathrm{m} 3$ for the months of December and January respectively.

Concentration of TSP in the wet months of May and June ranged from $16.0 \mu \mathrm{g} / \mathrm{m}^{3}$ to $31.0 \mu \mathrm{g} / \mathrm{m}^{3}$ and $320.4 \mu \mathrm{g} / \mathrm{m}^{3}$ to $557.9 \mu \mathrm{g} / \mathrm{m}^{3}$ in the dry months of December and January respectively. Concentrations obtained for the wet season months are seen to be markedly lower than that of the dry season months. Mean concentration of TSP is given as $22.0 \pm 4.02 \mu \mathrm{g} / \mathrm{m}^{3}$ for wet season and $447.0 \pm 77.88 \mu \mathrm{g} / \mathrm{m}^{3}$ for dry season. Test of significance showed dry to be significantly different from wet $\left[\mathrm{t}_{\text {stat }}(12.32)>\mathrm{t}_{\text {crit }}(6.96)\right]$.

\section{TEMPORAL DISTRIBUTION / SEASONAL VARIATION}

Particulates: Temporal distribution of TSP and $\mathrm{PM}_{10}$ across all stations indicates low concentration at control stations and highs at midpoint and downwind stations. Mean concentration of TSP was $447.2 \pm 75.4 \mu \mathrm{g} / \mathrm{m}^{3}$ for the months of December and January and $297.5 \pm 66.85 \mu \mathrm{g} / \mathrm{m}^{3}$ for $\mathrm{PM}_{10}$. Figures 1 and 2 are bar graph presentations of TSP and $\mathrm{PM}_{10}$ at downwind station.

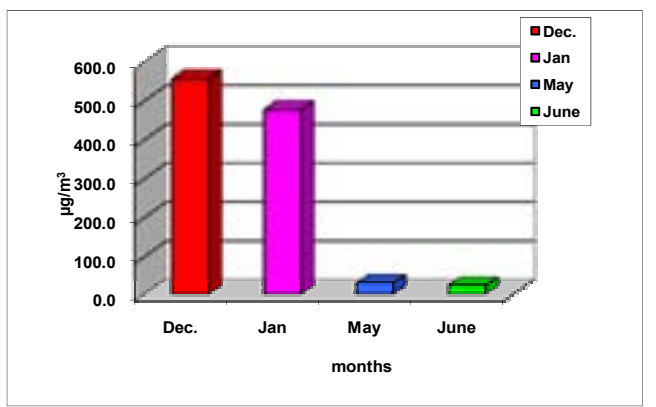

Fig. 2: Temporal distribution of $\mathrm{PM}_{10}$ at Downwind station (Dec. 07 - Jan. 08)

Seasonal variation of $\mathrm{PM}_{10}$ indicates a pattern of dry season highs and rainy season lows for $\mathrm{PM}_{10}$. Concentrations of $\mathrm{PM}_{10}$ in the wet months of May and June ranged from $14.0 \mu \mathrm{g} / \mathrm{m}^{3}$ to $24.0 \mu \mathrm{g} / \mathrm{m}^{3}$; and $250.1 \mu \mathrm{g} / \mathrm{m}^{3}$ to $391.1 \mu \mathrm{g} / \mathrm{m}^{3}$ in the dry months of December and January respectively. Concentrations obtained for the wet season months are seen to be significantly lower than that of the dry season months. Mean concentration of $\mathrm{PM}_{10}$ is given as $17.8 \pm 1.9 \mu \mathrm{g} / \mathrm{m}^{3}$ for wet season and 297.5 $\pm 66.03 \mu \mathrm{g} / \mathrm{m}^{3}$ for dry season. Test show significant variation between wet and dry. $\left[\mathrm{t}_{\text {stat }}(7.17)>\mathrm{t}_{\text {crit }}\right.$ (6.96) 0.01]. 
Figures 3 and 4 are bar graph presentations of the seasonal variations of TSP and $\mathrm{PM}_{10}$ respectively.

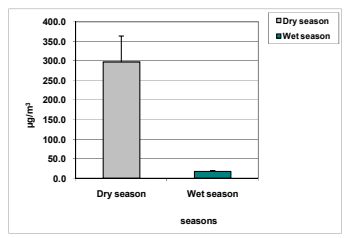

Fig. 3: Seasonal variation of two seasons (dry \& wet) of TSP across the four stations

The results suggests that the uniquely high levels of TSP, $\mathrm{PM}_{10}$ and $\mathrm{PM}_{7}$ observed during the dry months across all stations about Agabada II were attributable to the high content of dust particles from the North - East Trade wind (Hamarttan) which is the prevailing weather pattern at that time of the year and not entirely from gas flaring. The high levels of particulates in the dry season constituted a greater short term exposure risk to residents and workers in the vicinity of Agbada II flow station, with the particular risk of respiratory irritation, cough and eye irritation being endemic in the area surrounding the flare.

Particulates in the wet season months showed peak concentration values much lower than the recommended national limits; a factor attributable to the cleaning out effects of rain on the

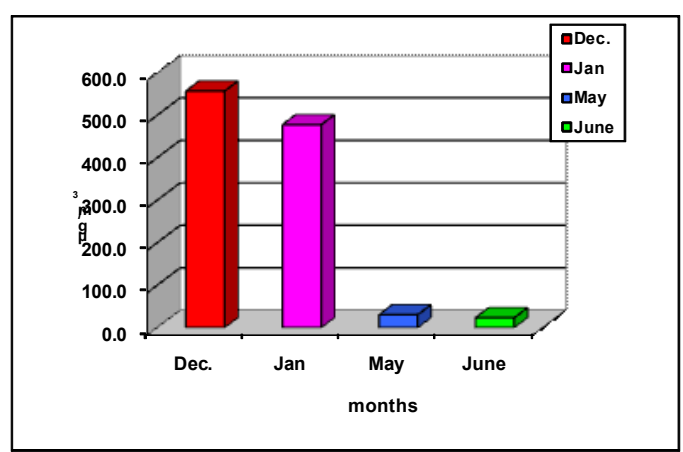

Fig. 5: Temporal distribution of VOC in Downwind station

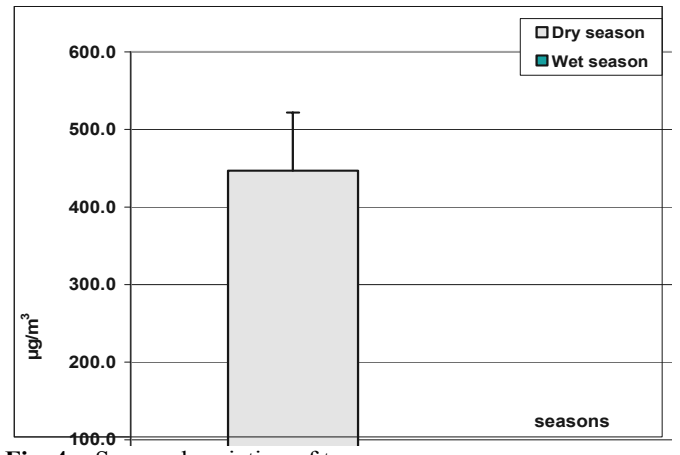

Fig. 4: Seasonal variation of two seasons

(dry \& wet) of $\mathrm{PM}_{10}$ across the four stations

atmosphere. The research findings also show that the mean concentrations of particulates and gases across all stations exhibit seasonal variations with peak concentrations in the dry season months of December and January.

\section{GASES}

TEMPORAL DISTRIBUTION / SEASONAL VARIATION

Volatile Organic Compounds (VOCs): The distribution of VOCs indicates that concentration of VOCs $<0.1 \mu \mathrm{g} / \mathrm{m}^{3}$ was recorded at control station and the concentration of $14.0 \mu \mathrm{g} / \mathrm{m}^{3}$ was recorded at downwind station. Figures 5 and 6 are bar graph presentations of the temporal distribution of VOCs and $\mathrm{CO}$ at downwind station.

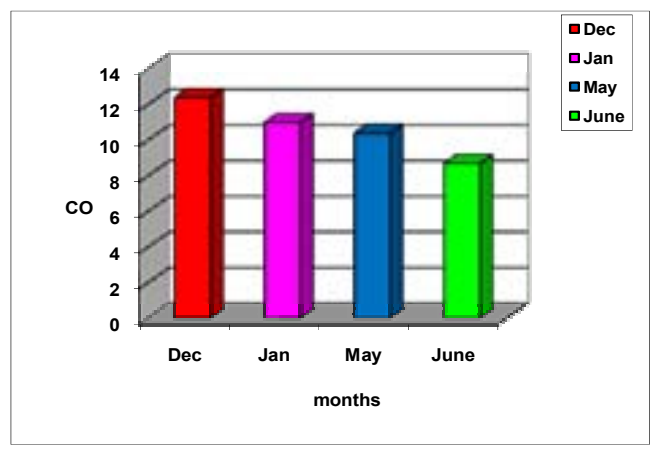

Fig. 6: Temporal distribution of $\mathrm{CO}$ in Downwind
The seasonal variation of VOC indicates no significant difference in the level of VOC recorded in both wet and dry seasons. Mean concentration of VOC is given as $5.9 \pm 6.8 \mu \mathrm{g} / \mathrm{m}^{3}$ for wet season and $6.7 \pm 7.5 \mu \mathrm{g} / \mathrm{m}^{3}$ for dry season. Mean concentration at control station was $0.1 \mu \mathrm{g} / \mathrm{m}^{3}$. Test of significance indicates dry not significantly different from wet, [ $\left.\mathrm{t}_{\text {stat }}(0.21)<\mathrm{t}_{\text {crit }}(2.62) 0.01\right]$.
Seasonal variation of $\mathrm{CO}$ indicates no variations in the concentration of $\mathrm{CO}$ in wet and dry seasons. Mean concentration of $\mathrm{CO}$ is given as $4.4 \pm$ $5.0 \mu \mathrm{g} / \mathrm{m}^{3}$ for wet season and $5.7 \pm 6.6 \mu \mathrm{g} / \mathrm{m}^{3}$ for dry season. Test of significance showed dry not significantly different from wet, [ $\mathrm{t}_{\text {stat }}(0.5)<\mathrm{t}_{\text {crit }}$ (1.76) 0.01]. Figures $7 \& 8$ below are bar graph presentations of the seasonal variation of VOCs and $\mathrm{CO}$ with stdev. respectively. 


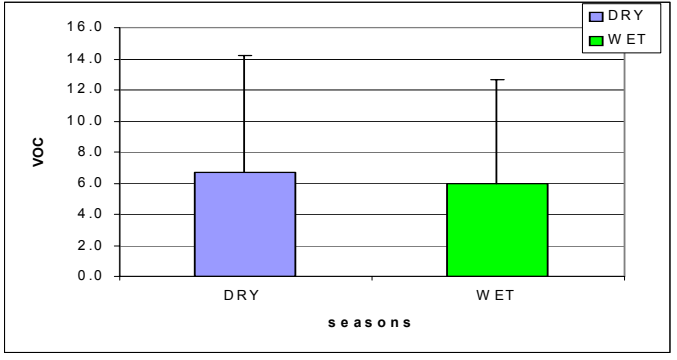

Fig.7: Seasonal variation of VOC with stedv for two seasons (wet $\&$ dry)

The research further indicates that concentration of Gases and VOCs across all sites in Agbada II remained markedly lower than the allowed regulatory limits. This however, does not mean that

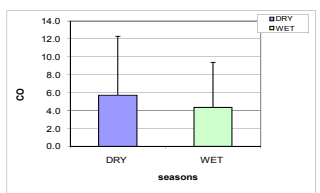

Fig. 8: Seasonal variation of $\mathrm{CO}$ with stedv. for two seasons (wet \& dry)

Sulphur oxides, Nitrogen oxides and other gases do not play a role in disease distribution in Igwuruta/Umuechem area, or indeed in the Niger Delta region.

\section{MEDICAL STATISTICS}

Table 4: disease distribution of Igwuruta (2004 - 2007)

\begin{tabular}{llllll}
\hline Type & Frequency & $\mathbf{\%}$ & Type & Frequency & $\mathbf{\%}$ \\
Fever & & 29.1 & Skin disease/itching & 18 & 2.2 \\
Cough & 243 & 17.1 & Malaria & 16 & 1.9 \\
Loss of appetite & 66 & 7.9 & Bleeding & 15 & 1.8 \\
Stooling/dysentry & & 6.7 & & & 1.4 \\
Cattarrh/ cold & 56 & 6.3 & Weight loss & 4 & 0.5 \\
Vomitting & 53 & 6 & Chest pain & 3 & 0.4 \\
Body weakness & 50 & 4.2 & Dizziness & 8 & 1 \\
Boil & 35 & 3.2 & Pneumonia & 2 & 0.2 \\
Breathing difficulties & 27 & 2.5 & & & 0.4 \\
Headache & 21 & 2.3 & Constipation & 8 & 1 \\
Abdominal pain & 19 & 2.3 & Eye irritation & 11 & 1.3 \\
& 19 & & Asthma & 4 & 0.5 \\
\hline
\end{tabular}

Table 5: Disease distribution of Ayama in (2004 - 2007)

\begin{tabular}{|c|c|c|c|c|c|}
\hline Type & Frequency & $\%$ & Disease types & Frequency & $\%$ \\
\hline Fever & 170 & 20.1 & Skin disease/itching & 3 & 0.4 \\
\hline Cough & 40 & 4.7 & Muscle pain & 10 & 1.2 \\
\hline Loss of appetite & 50 & 5.9 & Pneumonia & 2 & 0.2 \\
\hline Bleeding & 5 & 0.6 & Cattarrh/cold & 150 & 17.8 \\
\hline Weight loss & 6 & 0.7 & Vomiting & 30 & 3.6 \\
\hline Chest pain & 2 & 0.2 & Dizziness & 2 & 0.2 \\
\hline Body weakness & 32 & 3.8 & Stooling/dysentry & 170 & 20.1 \\
\hline BOIL & 30 & 3.6 & MISEALES & 4 & 0.5 \\
\hline $\begin{array}{l}\text { Breathing } \\
\text { difficulties }\end{array}$ & 5 & 0.6 & Constipation & 15 & 1.8 \\
\hline Headache & 90 & 10.7 & Eye irritation & 4 & 0.5 \\
\hline Abdominal pain & 24 & 2.8 & Asthma & 1 & 0.1 \\
\hline
\end{tabular}

Tables 4 and 5 above are statistical data obtained from Igwuruta/Umuechem and Ayama health centres respectively. 
Information gleaned from these medical records indicates that the most prevalent cases at Igwuruta were Fever with a frequency of 243 or $29.1 \%$, Cough with a frequency of 143 or $17.1 \%$ and Loss of appetite, Diarrhoea/Dysentry and Catarrh/Cold, each with a frequency of 66,56 , and 53 accounting for $7.9 \%, 6.7 \%$ and $6.3 \%$ respectively.

The least common cases were Pneumonia with a frequency of 2 or $0.2 \%$, Chest pain and Measles each with a frequency of 3 or $0.4 \%$ respectively.

Similarly the most prevalent cases at Ayama were Fever/Malaria and Diarrhoea/Dysentry each representing frequencies of 170 or $20.1 \%$ respectively, catarrh/Cold has a frequency of 150 or $17.8 \%$ and Headache accounted for a frequency of 90 or $10.7 \%$ of all reported cases at Ayama health centre. Health conditions such as asthma, cough, breathing difficulty, eye irritation and dizziness which are commonly associated with air pollution occur more frequently in Igwuruta/Umuechem area than in Ayama and accounted for $22.4 \%$ of all cases recorded at lgwuruta health centre, and this is almost a quadruple of that for the Abua/Odual axis with $5.9 \%$ of recorded cases according to available records.

CONCLUSION: Research findings show that there is indeed a correlation between environmental variables resulting from gas flaring and the development of certain ailments found in individuals residing in such area. In addition to this, this paper attempts to isolate cases and determine whether other factors (i.e. other than gas flaring activities) might be responsible for the rate of certain medical conditions being witnessed in the research area. Although the research was unable to detect the role of individual compounds in disease distribution, it recorded spikes in the concentration of some variables, particularly $\mathrm{PM}_{7}$, $\mathrm{PM}_{10}$, and TSP in the dry season months of December and January. It was further determined that the available health facilities in the locale are neither equipped to identify the conditions being experienced by the locals or to cater for these conditions other than to provide basic relief alleviating the symptoms of these conditions but not their root causes. While the experiences acquired through the clinic session and research findings suggests that variations in environmental pollutants may be responsible for the anomalies seen, the researcher acknowledges that other detrimental activities such as smoking, improper sanitary conditions and other factors may exacerbate it.

\section{REFERENCES}

Abbey, D.E., Peterson, F., Mills, P.K.C and Beeson, W.L (1993) Long-term ambient concentrations of total suspended particulates, ozone, Sulphur dioxide and respiratory symptoms in a non-smoking population. Archives of Environmental Health, 33-46.

Calabrese, E.J., and Kenyon, E.M (1991). Air Toxics and Risk Assessment. Lewis Publishers, Chelsea, M.

Egbuna, D.O (1987). The Environmental Hazards of the Nigerian Natural Gas Industry, pp. 346.

Godson, R.E.E; Mynepalli, K.C, and Olawuyi, J.F (2005). "Air pollution in a chemical fertilizer complex in Nigeria: The impact on the health of the workers". JEHR,. Harrison, R. A. 1995, $A \& A, 304,585$.

Hall, H.I., Price-Green, P.A., Dohara, V.R. and Kaye, W.E (1995). "Health effects related to release of hazardous substances on superfund priority list", Chemosphere 31, 2455-2461.

James, Argo (2001) Unhealthy effects of upstream oil and gas flaring. International Americas Centre for Environment and Health, pg. 7-35.

Pope, A. and Dockery, D (1996). Epidemiology of chronic health effects. Published by Harvard University Press, chapter 6, 7.

Stewart, P., Siematycki, J., Gertin, M., Nadon, L., and Dewar, R (1988). Association between several sites of cancer and ten types of exhaust and combustion products. Scand. J. Work Environ, Health. 14, 79 - 90.

Wieslander, G., Norback, D., and Edling, C (1994). "Occupational exposure to water based paint and symptoms from skin and eyes." Occupational and Environmental Medicine, 51, 181-186. 